\title{
The Strategy of Science Process Skills Development in Chemistry Learning of Junior High School Level in The Era of Covid-19 Pandemic
}

\author{
I Komang Wisnu Budi Wijaya ${ }^{1}$, Ni Putu Juni Artini ${ }^{2}$, Ni Kadek Ayu Kristiandayanti ${ }^{3}$, L. \\ Virginayoga Hignasari ${ }^{4}$, I Putu Oktap Indrawan ${ }^{5}$, I Gusti Ayu Agung Sinta Diarini ${ }^{6}$ \\ \{wisnu.budiwijaya240191@ gmail.com ${ }^{1}$, juniartini77@yahoo.co.id ${ }^{2}$, \\ kkristiandayanti@baliis.net ${ }^{3}$, ginahignasari@gmail.com ${ }^{4}$, oktap8indrawan@gmail.com ${ }^{5}$, \\ gungsinta@undhirabali.ac.id $\left.{ }^{6}\right\}$ \\ Jurusan Pendidikan Guru Sekolah Dasar, Universitas Hindu Negeri I Gusti Bagus Sugriwa \\ Denpasar, Jalan Ratna, Denpasar, 80237, Indonesia ${ }^{1}$ \\ Jurusan Pendidikan Guru Sekolah Dasar, Universitas Triatma Mulya, Jalan Danau Batur, \\ Jembrana, 82218, Indonesia ${ }^{2}$ \\ Bali Island School, Jalan Danau Buyan, Denpasar, 80227, Indonesia ${ }^{3}$ \\ Jurusan Teknik Industri, Universitas Mahendradatta, Jalan Ken Arok, Denpasar, 80115, \\ Indonesia ${ }^{4}$ \\ Jurusan Manajemen Informatika Politeknik Ganesha Guru, Jalan Banyuasri Buleleng, 81113, \\ Indonesia $^{5}$ \\ Jurusan Pendidikan Kesejahteraan Keluarga, Universitas Dhyana Pura, Jalan Raya Padang \\ Luwih Badung, 80361, Indonesia ${ }^{6}$
}

\begin{abstract}
Abtract. The Indonesian Government implements learning from home policy as a form of adaptation to learning activities in the era of Covid-19 pandemic. Even though students are learning from home, the quality of learning should be prioritized. A quality chemistry learning is a chemistry learning which develops a science process skills. This research aims to examine the strategy of science process skills development in chemistry learning of junior high school level in the era of Covid-19 pandemic. This research is categorized as a literature study by collected data from books, journals, and other resources. The analysis technique used is the content analysis technique, it is a scientific analysis technique of the content from various sources. The result of the study states that can be done by implementing computer media and carrying out learning activities in the form of practicum using equipment and materials available at home.
\end{abstract}

Keyword: chemistry learning, covid-19, science process skills, strategy

\section{Introduction}

Basically, natural science is the study of various phenomena in nature. Natural science is the study that has an object and using the scientific method (Samatowa, 2011). Natural science can be viewed as product, process, and attitude. As a product, natural sciences consist of some concepts, principles, theory, basis, and law. As a process, all of those natural sciences products obtained from systematically process, known as the scientific method. Meanwhile, as 
an attitude, Scientists find various natural science products through the scientific method based on some attitudes such as curiosity, honesty, hard work and open (Mariana \& Praginda, 2009).

Science is a branch of science that can develop skills in the $21^{\text {st }}$ century (Suryandari, Sajidan, Rahardjo, Prasetyo, \& Fatimah, 2018). Therefore, science learning should accommodate the essence of science, which is carried out by conceptual approach and science process skills. The conceptual approach is a way of looking at science learning which states that the process of learning emphasizes the students' mastery of concepts. The concept is explored and discovered by the students themselves through scientific activities. Thus, the science process skill approach is the learning approach which aims to train students related to the skills used in the scientific method, such as observation, hypothesizing, designing experiments and other skills. Students' science process skills is important aspects that must be possessed in learning science (Tanti, Kurniawan, Kuswanto, Utami, \& Wardhana, 2020). Science learning with science process skills makes them able to describe concepts, make predictions, raise questions, examine predictions and interpret data (Ratnasari, Sukarmin, Suparmi, \& Harjunowibowo, 2018). Other than that, Scientific process skills are one of the most important basic science skills of the $21^{\text {st }}$ century (Gunawan, Harjono, Hermansyah, \& Herayanti, 2019).

Chemistry is a part of the sciences. Therefore, it has the same characteristics as the sciences (Redhana \& Suardana, 2021). Chemistry is a study of matter, properties, and changes of matter including the energy involve in the changing. The study of chemistry consists of 3 (three) things, namely macroscopic, microscopic, and symbolic . Macroscopic is the study of chemistry which could be observed by the naked eye in daily life. Microscopic is the study of particles composing matter (Johnstone, 1993). On the other hand, symbolism is the study of symbols that represents the chemical phenomena or well known as "chemical language" (Artini \& Wijaya, 2020). These three aspects are closely related to one another.

In Indonesia, chemistry learning is given at junior high school and senior high school level (Wijaya, Suastra, \& Muderawan, 2014). At the junior high school level, chemistry learning is carried out in an integrated manner on science subjects, meanwhile at the senior high school level chemistry learning is carried out in a separate system. The objective of learning chemistry is that the human resources in Indonesia has a good understanding of chemical concepts and the ability to apply the concepts in daily life. Chemistry learning is important for the students. It is one of the prior step for the students to identify and understand the concepts of nature to build the proficiency and thinking ability in order to play an active role in applying their knowledge in the world of technology. (Ulianta, Sukardjo, \& Priono, 2020).

As part of science, chemistry learning should be carried out by science process skills approach. Science process skills is a thinking skill, reasoning skill and act logically to research and build a basic science concept that can be able to solve science problems (Retno \& Yuhanna, 2019). Science process skills are very important to be instilled to the science students because it is very useful in solving daily life problems related to science. In addition, learning with science process skills approach makes the process of science learning more interesting because students are actively involved in the learning process.

The Covid-19 pandemic has changed the learning system in Indonesia including chemistry learning at the junior high school level. Indonesia government through the Ministry of Education and Culture gives instruction that learning is carried out with the concept of "Learn From Home". This is the learning concept which is carried out by teachers and students at home by minimizing face to face activities and utilizing online learning facility. Learning with 
the concept of "learn from home" become the most effective mitigation step for minimizing the deployment of Covid-19 epidemic to the students (Herliandry, Nurhasanah, Suban, \& Kuswanto, 2020). Even though the learning system has changed, the quality of chemistry learning at the junior high school level should be maintained. One of the quality chemistry learning indicators is the learning that instills science process skills to students. Moreover, chemistry topics at the junior high school level are very close to daily life, so that is still possible to instill the science process skills in the learning process. This can be done by carrying out computer-based learning and doing chemistry practicum by utilizing equipment and materials available at students' homes. In this paper, it will be explained how the strategy of science process skills development in chemistry learning in the era of Covid-19 pandemic.

\section{Method}

This research is categorized as a literature study. A literature study is a type of research by collecting data and information deeply related to the research object as the main characteristic. This research was conducted by examining various resources such as books, journals, and other resources related to science process skills, chemistry learning, and learning in the era of Covid 19 pandemic. The data analysis technique uses content analysis technique which are a scientific analysis of a data message or literature.

\section{Results and Discussion}

\subsection{Science Process Skills}

Science process skills is a form of science as a process (Verawati \& Prayogi, 2016). Science process skills are also, skills used by the scientists to investigates natural phenomena where these skills can be trained to the students according to their stage of development (Risamasu, 2016). Science process skills should be instilled in all science students and their branches of science, namely chemistry, physic, and biology. There are some reasons why science process skills are very important to instill, namely as follows:

1. Now days, The science development is taking place so fast, so it's not possible for the teachers to teach all of the science products to the students.

2. Generally, students will be easy to understand the complex science concepts if accompanied with concrete examples and finding the concept through experimental activities.

3. Basically, all science products are tentative which still can be questioned, corrected or even denied.

4. The science learning process must pay attention to the development of students' attitudes and values (Semiawan, 1992).

Science process skills consist of several types. Each science process skill has its own indicator. The type of science process skills and the indicators can be seen in Table 1.

Table 1. Types of Science process skills and their indicators

\begin{tabular}{lll}
\hline No & Science Process Skills & Indicators \\
\hline 1 & Observing & Use senses \\
& & Collect facts
\end{tabular}




\begin{tabular}{|c|c|c|}
\hline & & Look for similarities and differences \\
\hline & & Classify \\
\hline \multirow[t]{4}{*}{2} & Interpreting & Record the observation result \\
\hline & & Connect the observation result \\
\hline & & Find a pattern \\
\hline & & Draw a conclusion \\
\hline 3 & Predicting & Explain the possibilities of what might happen \\
\hline 4 & Using equipment and materials & Skilled in using materials/equipment \\
\hline \multirow[t]{3}{*}{5} & Applying concepts & Apply concepts in the new situation \\
\hline & & Explain what happen \\
\hline & & Set a hypothesis \\
\hline \multirow[t]{4}{*}{6} & Designing an experiment & $\begin{array}{l}\text { Determine the materials, equipment, and sources used. } \\
\text { Determine the variables. }\end{array}$ \\
\hline & & Determine the dependent and independent variables. \\
\hline & & $\begin{array}{l}\text { Determine what will be observed Determine the } \\
\text { procedure }\end{array}$ \\
\hline & & Determine how to process the observation result. \\
\hline \multirow[t]{4}{*}{7} & Communicating & Arrange and communicate the report \\
\hline & & Explain the result of observation \\
\hline & & Discuss the result of experiment \\
\hline & & $\begin{array}{l}\text { Describe data in form of graph, table and etc. } \\
\text { Read the graph and table. }\end{array}$ \\
\hline \multirow[t]{3}{*}{8} & Asking & Ask what, how and why \\
\hline & & Ask to get an explanation \\
\hline & & Ask a hypothetical question \\
\hline
\end{tabular}

(Source :Suastra, 2008)

On the Tabel 1 showed that each aspect of science process skills has clear and measurable indicator. Science process skills can be learned by students a simple form based on the development stages of students in junior high school level. Science process skills can be developed if students are active in the learning process. Students are situated to read individually, relate the new concepts by discussion and using new terms, concepts and principles through a set of learning activity (A'yun \& Subali, 2018).

There are five aspects that need to be considered in helping students develop the science process skills, namely providing opportunities to: (1) use science process skills to explore the material and phenomena closely, (2) Discuss in small group and classroom discussion, (3) listen to their words and study the result to know their way of thinking, (4) encourage critically review of how the activity is completed, (5) introduce techniques that require further skills. By developing science process skills, students will be able to discover and develop their own facts and concepts as well as growing and developing the required value attitudes. Thus, these skills become a driving force for the discovery and development of facts and concepts as well as the growth and development of attitudes and values.

\subsection{Chemistry in Junior High School Level}

Chemistry has become part of the subjects taught at the junior high school level since the implementation of the Education Unit Level Curriculum (KTSP). This subject is taught in an 
integrated manner on a science subjects. There are several things that encourage chemistry at junior high school level to be integrated with the science subject, such as (1) In some country, chemical study materials have been given in junior high school and even in elementary school level such as in England, Philippine, Singapore, and Australia, (2) Demands of the international world (through International Science Olympiad) where the problems issued are also include chemistry, (3) Based on the students' needs. On this basis, the government took a positive step by incorporating chemistry subject into science subject (Salirawati, 2008).

In the 2013 curriculum that applies in Indonesia, chemistry still become part of the science subject at the junior high school level. The scope of chemistry topics for junior high school students are shown in Table 2.

Table 2. The Scope of Chemistry Topic in Junior High School Level

\begin{tabular}{|c|c|c|c|c|}
\hline \multicolumn{2}{|c|}{ No } & \multicolumn{2}{|l|}{ Basic Competences } & Topic \\
\hline 1 & O & $\begin{array}{l}\text { Explaining the concept of mixture and } \\
\text { single substance (element and } \\
\text { compound), physical and chemical } \\
\text { properties, physical and chemical changes } \\
\text { in daily life (knowledge). } \\
\text { Presenting the result of investigation or } \\
\text { work about the properties of solution, } \\
\text { physical and chemical changes or } \\
\text { separation of a mixture } \\
\text { (Skill) }\end{array}$ & $\begin{array}{l}0 \\
0\end{array}$ & $\begin{array}{l}\text { Element, } \\
\text { compound and } \\
\text { mixture } \\
\text { Mixture separation } \\
\text { Physical and } \\
\text { chemical } \\
\text { properties } \\
\text { Physical and } \\
\text { chemical changes } \\
\text { Acid, base and salt }\end{array}$ \\
\hline 2 & ○ & $\begin{array}{l}\text { Explaining various additives in food and } \\
\text { beverage, addictive substances, as well as } \\
\text { their impact on health (Knowledge) } \\
\text { Writing a scientific paper about the } \\
\text { impact of additives and addictive abuse } \\
\text { for health (Skill) }\end{array}$ & ○ & $\begin{array}{l}\text { Additives on food } \\
\text { and beverages } \\
\text { Narcotics, } \\
\text { psychotropics, and } \\
\text { other addictive } \\
\text { substances }\end{array}$ \\
\hline 3 & ○ & $\begin{array}{l}\text { Connecting the concept of particle matter } \\
\text { (atom, ion, molecule), the structure of } \\
\text { simple substance with the properties of } \\
\text { materials used in daily life, as well as the } \\
\text { impact of their use on human health. } \\
\text { (Knowledge) } \\
\text { Presenting the result of investigation } \\
\text { about the properties and utilization of } \\
\text { materials in daily life (Skill) }\end{array}$ & ० & $\begin{array}{l}\text { Atom, Ion, and } \\
\text { molecule }\end{array}$ \\
\hline
\end{tabular}

Chemistry learning in the junior high school level has the following characteristics: 1) adjusted to the cognitive, affective, and psychomotor development of junior high school students; 2) carried out by scientific approach; 3) the topics presented are related to the chemical concepts in daily life; 4) concerning macroscopic, microscopic, and symbolic aspects and 5) emphasizing the concept mastery and science process skills development. In the learning process, students are expected to be the main actors or it's known as students' centered learning. The teachers act as a facilitator when students experience difficulties or find obstacles in chemistry learning. 


\subsection{Science Process Skills Development}

Chemistry learning in the junior high school level should have considered the development of science process skills to the students, although currently in the Covid-19 pandemic situation. This can be done in two ways, namely carrying out learning by using computerbased learning media and carrying out chemistry practicum by using materials and equipment available at home. The explanation of each follows:

\subsubsection{Computer-Based Chemistry Learning}

Computer-based chemistry learning is the learning of chemistry using computers as learning media or source of learning. Technological development, especially computers that are growing rapidly has given an influence on the implementation of chemistry learning (Sulistiyarini \& Sabirin, 2020). Technology leads the learning instruction not always conducted by face-to-face learning but also through the online learning (Fitriyana dkk, 2020). One of them is the advance of computer-based information technology provides an opportunity in creating learning materials to support learning using the inquiry approach. This technological advancement makes it easy in designing learning media to bring real phenomena, in the form of laboratory facts video and daily life into inquiry class. There are several advantages using computer-based media in chemistry learning, such as (1) the experiment can be faster; (2) the experiment design can be more complex; and (3) more focus on the theory aspect (Wijaya, Kirna, \& Suardana, 2012).

The learning forms of computer-based learning media such as 1) drill and practice, 2) tutorial, 3) games, and 4) simulation. The drill and practice is generally used for exam/test preparation and presenting problems practice. The tutorial contains instructions for solving problems or on how to design an experiment. The simulation contains practicums that are done virtually where students can do manipulation of some variables or it also can be referred to as virtual laboratories. The instructional games generally used for creating a fun learning ambiance (Amanah, 2016).

The chemistry learning forms that are able to develop science process skills, namely by tutorial and simulation. If the teacher wants a tutorial form, so that the teacher must inform first the learning objectives and learning topics and continued by sharing a video or a video link about tutorials of doing experiments. Currently, many are available on the internet related to a video guidelines of chemistry practicum in junior high school students level. On of them is uploaded on Youtube at the following link https://www.youtube.com/watch?v=_ZOiiZGCun4, is_shown in Figure 1. 


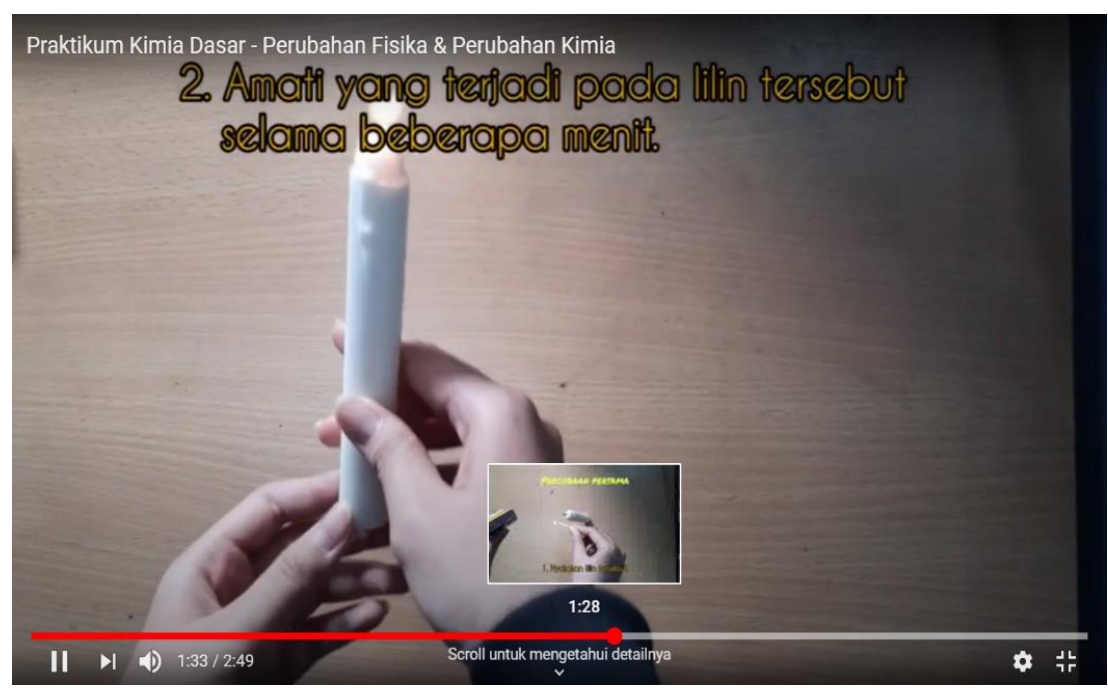

Fig 1. Practicum Tutorial Preview of Physical and Chemical Changes (Source : www.youtube.com)

In this tutorial is presented about how to do the physical and chemical changes practicum. The video is explained about materials and equipment that should be prepared and the practicum procedure. This can help students in developing two aspects of the science process skills, namely observation ability and experimental design ability.

The second form is practicum simulation-based learning or known as virtual laboratories. Virtual laboratory media is one type of digital media (Saputro \& Setyawan, 2020). At the moment, computer technology has been able to provide some virtual laboratory facilities for chemistry learning in junior high school. These facilities are also available directly on the internet or can be designed individually by using various software. In implementing the virtual laboratories to the learning activities, the teacher must explain first how to use it. The examples of virtual laboratories about acid and base practicum which is developed by using Adobe Flash CS 3 software are shown in Figure 2, 3, and 4.

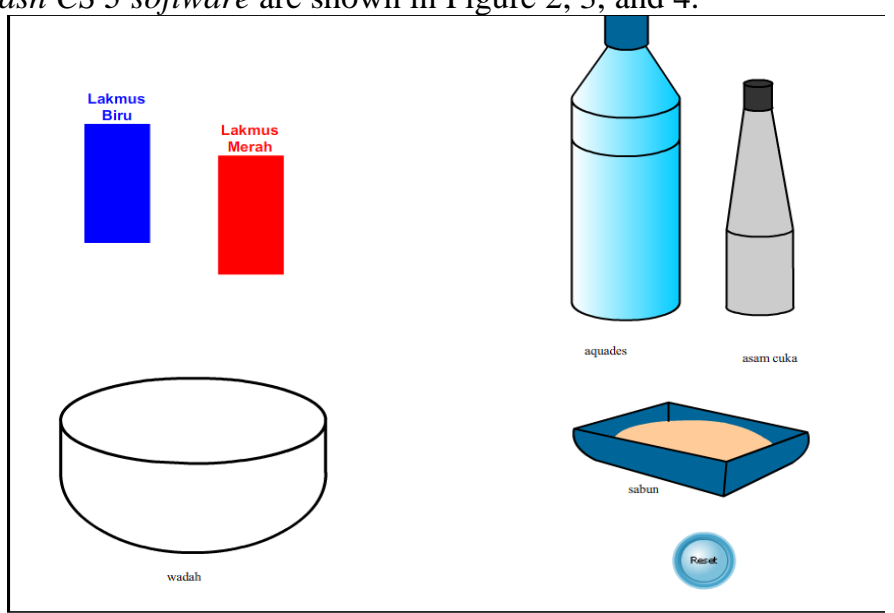

Fig 2. Introduction Preview of Acid Base Practicum (Source:

https://www.indolearn.com/post/2018/multimedia-interaktif-flash-percobaan-kimia-asam-basa/) 


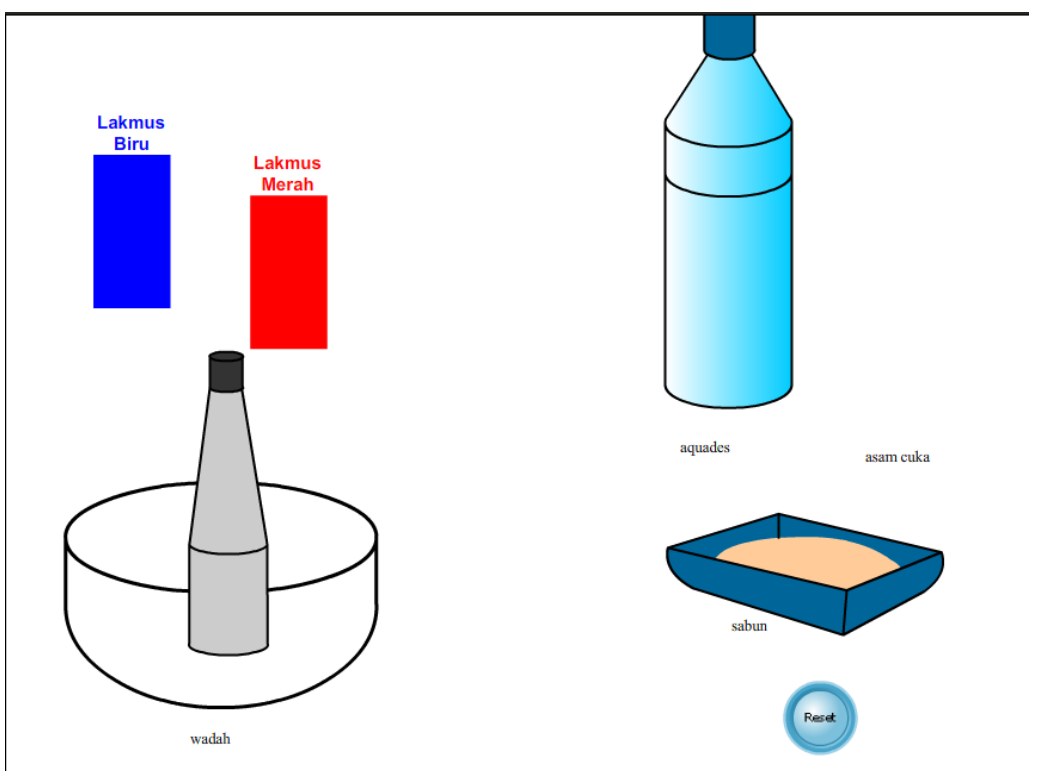

Fig 3. Vinegar Solution is put to the container (Source:

https://www.indolearn.com/post/2018/multimedia-interaktif-flash-percobaan-kimia-asam-basa/)

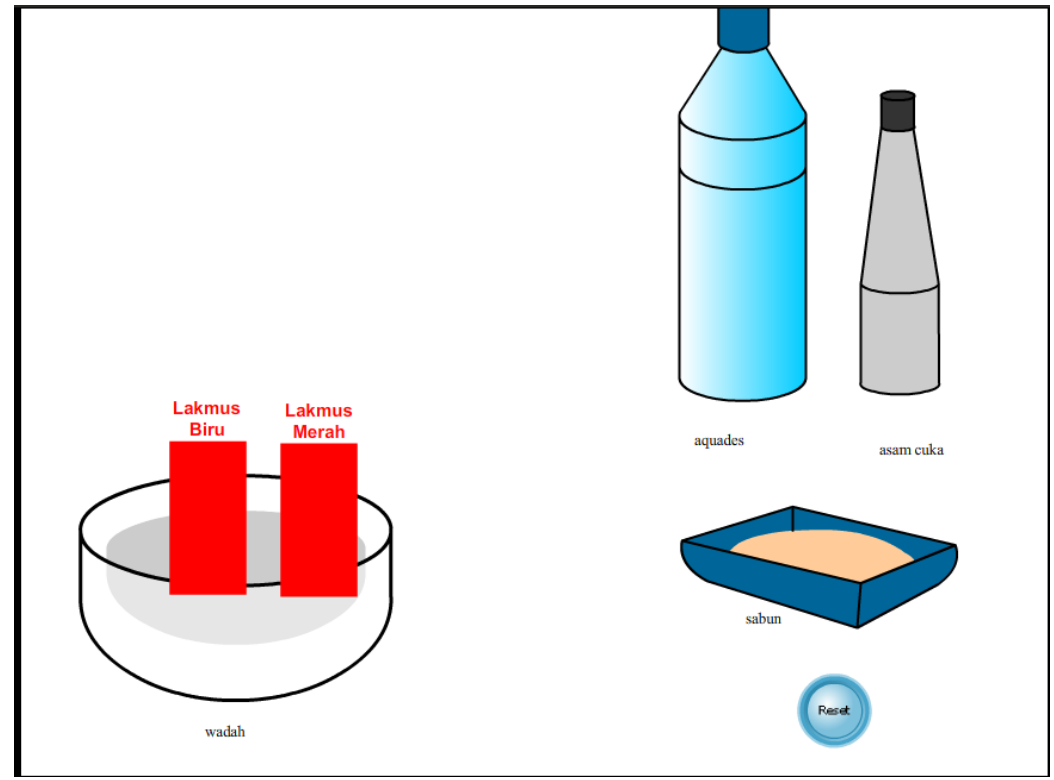

Fig 4. Litmus Paper is dipped into vinegar and color changes happened (Source: https://www.indolearn.com/post/2018/multimedia-interaktif-flash-percobaan-kimia-asam-basa/)

This form of practicum simulation help students to develop various science process skill, namely observing, designing an experiment, interpreting and using materials and equipment. Looking at the advantages that are presented, the computer technology is worth to apply in 
chemistry learning activities especially in junior high school. The reasons underlying the needs of integrating computer technology into learning activities, especially chemistry learning are: (1) with the presence of computer technology in learning activities, there will be a shift in the learning paradigm from teacher-centered to student-centered, (2) Integrated learning model with computer technology is active and collaborative learning model, and (3) computer technology can improve motivation, skill, and thinking structure (Sutrisno, 2011).

\subsubsection{Chemistry Practicum at Home}

Chemistry is not a study of being in a laboratory only, but it is a study that can be everywhere, including at home. Therefore, chemistry practicum also can be done at home by utilizing equipment and materials at home. In implementing chemistry practicum at home, the steps that should be done by the teacher to the student are informing the learning objectives and a summary of the topics verbally or written, giving a practicum guidelines and tasks to students to make a practicum report. The examples of chemistry practicum activities that can be done at home are as follows:

Table 3. The Examples of Chemistry Practicum at home in Junior High School Level

\begin{tabular}{|c|c|c|c|c|}
\hline No & Topics & $\begin{array}{l}\text { Practicum } \\
\text { Objectives }\end{array}$ & Method & Science Process Skills \\
\hline 1 & $\begin{array}{l}\text { Acid } \\
\text { and } \\
\text { Base }\end{array}$ & $\begin{array}{l}\text { Making a } \\
\text { natural acid } \\
\text { base } \\
\text { indicator } \\
\text { from } \\
\text { turmeric. }\end{array}$ & $\begin{array}{l}\text { Equipment: grater, bowl, } \\
\text { sieve, mortar and three } \\
\text { small cups } \\
\text { Materials: sufficiently } \\
\text { turmeric, warm water, } \\
\text { lime, table salt, antacid } \\
\text { tablet. } \\
\text { Procedure: } \\
\text { Peel the turmeric until all } \\
\text { clean, grate the turmeric } \\
\text { and when it is all grated } \\
\text { add some warm water, } \\
\text { strain the mixture with the } \\
\text { sieve and the filtrate is } \\
\text { placed in the bowl, } \\
\text { Squeeze the lime and } \\
\text { place it in a small glass, } \\
\text { dissolve table salt in the } \\
\text { other small glass which } \\
\text { has water in it, mash the } \\
\text { antacid tablet until it } \\
\text { smooth and put it into the } \\
\text { other small glass which } \\
\text { has water in it, stir it for a } \\
\text { couple of times. } \\
\text { Add each one tea spoon of } \\
\text { turmeric solution into the }\end{array}$ & $\begin{array}{l}\text { Observing, using } \\
\text { equipment } \\
\text { materials, designing an } \\
\text { experiment, } \\
\text { interpreting and } \\
\text { communicating }\end{array}$ \\
\hline
\end{tabular}




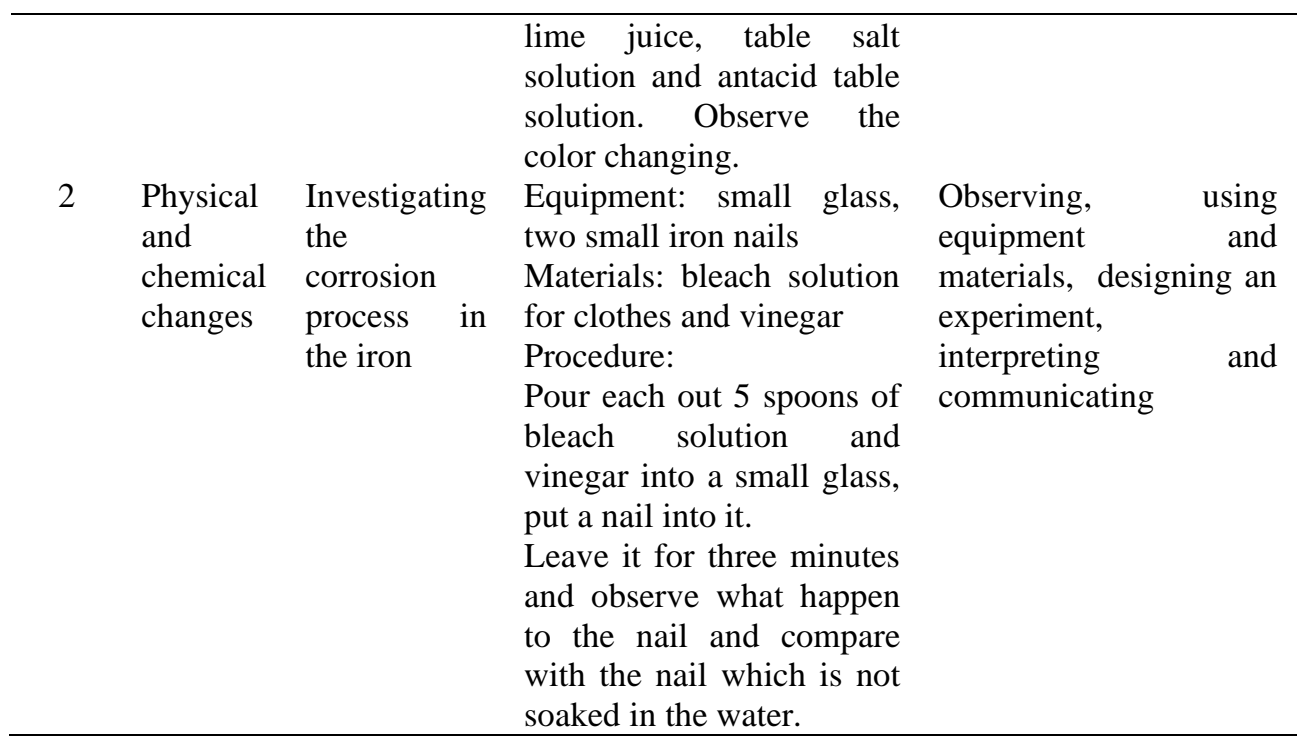

Based on the data presented in Table 3, it can be seen that various science process skill can be developed through chemistry practicum at home. Therefore, this activity can be a recommendation for the chemistry learning in junior high school level during the Covid-19 pandemic. The parents are expected to give support and supervision to the children when they are doing a chemistry practicum at home.

In developing science process skills for chemistry learning in junior high school, the roles of the teacher can not be ignored. The roles of the teacher are as a motivator, a learning planner, a facilitator, and an evaluator (Wijaya, 2019). As a motivator, the teacher should be able to motivate their students to study diligently especially chemistry subject during this Covid-19 pandemic. As a learning planner, the chemistry teacher (science) in junior high school level is expected to be able to design a computer-based chemistry learning properly or chemistry practicum at home, so that the students are able to develop the aspects of the science process skills. The role of the teacher as a facilitator is to help students when they have difficulties in developing science process skill through computer-based learning or practicum at home. Then, the role of the teacher as an evaluator is that the teacher is expected to be able to develop an evaluation system to measure the science process skills that their students have achieved.

\section{Conclusion}

The chemistry topics for junior high school students are really close to daily life. Therefore, it is appropriate for chemistry learning is carried out by developing science process skills. The development of science process skills must be carried out in chemistry learning for junior high school although there is a Covid-19 pandemic at the moment. This is can be done by doing computer-based chemistry learning with tutorial pattern and virtual laboratory simulations as well as inviting students to do chemistry practicum using equipment and materials available at home. Various science process skills can be developed through some activities such as observing, using equipment and materials, designing an experiment, 
interpreting, and the other science process skills. In developing the science process skills, the roles of the teacher are as a motivator, a learning planner, a facilitator, and an evaluator. This result of the study also gives meaning that science learning especially chemistry in the junior high school level is not only done at school and laboratory but also can be done at home. Apart from that, the result of this study also gives contribution in the chemistry education field particularly science process skills outside laboratory.

\section{References}

[1] A’yun, S. N., \& Subali, B. (2018). Sifat-Sifat Cahaya Dalam Discovery Learninguntuk Meningkatkan Keterampilan Proses Sains. Jurnal Ilmu Pendidikan, 24(2), 75-79.

[2] Amanah, S. (2016). Modul Guru Pembelajar Mata Pelajaran Kimia SMA Kelompok Kompetensi E. Bandung: P4TK IPA.

[3] Artini, N. P. J., \& Wijaya, I. K. W. B. (2020). Strategi Pengembangan Literasi Kimia Bagi Siswa SMP. Jurnal Ilmiah Pendidikan Citra Bakti, 7(2), 100-108.

[4] Gunawan, Harjono, A., Hermansyah, \& Herayanti, L. (2019). Guided Inquiry Model Through Virtual Laboratory To Enhance Students' Science Process Skills On Heat Concept. Cakrawala Pendidikan, 38(2), 259-268.

[5] Herliandry, L. D., Nurhasanah, Suban, M. E., \& Kuswanto, H. (2020). Pembelajaran Pada Masa Pandemi Covid-19. Jurnal Teknologi Pendidikan, 22(1), 65-70.

[6] Johnstone. (1993). The Development of Chemistry Teaching: A Changing Response to Changing Demand. Journal of Chemical Education, 70(9), 701-705.

[7] Mariana, I. M. A., \& Praginda, W. (2009). Hakekat IPA dan Pendidikan IPA. Bandung: P4TK IPA.

[8] Ratnasari, D., Sukarmin, Suparmi, \& Harjunowibowo, D. (2018). Analysis Of Science Process Skills Of Summative Test Items In Physics Of Grade X In Surakarta. Jurnal Pendidikan IPA Indonesia, 7(1), 34-40.

[9] Redhana, I. W., \& Suardana, I. N. (2021). Green Chemistry Practicums at Chemical Equilibrium Shift to Enhance Students' Learning Outcomes. International Journal of Instruction, 14(1), 691708.

[10] Retno, R. S., \& Yuhanna, W. L. (2019). Implementasi Green Living Berbasis Scientific Inquiry pada Pembelajaran IPA terhadap Kinerja Ilmiah Siswa. Primere Educandum, 8(1), 31-40.

[11] Risamasu. (2016). Peran Pendekatan Keterampilan Proses Sains Dalam Pembelajaran Ipa. Prosiding Seminar Nasional Pendidikan.

[12] Salirawati, D. (2008). Pengenalan Dan Pengkajian Materi Kimia SLTP Berdasarkan Kurikulum Berbasis Kompetensi Yang Terintegrasi Dalam Mata Pelajaran Sains. Yogyakarta: Universitas Negeri Yogyakarta.

[13] Samatowa, U. (2011). Pembelajaran IPA di Sekolah Dasar. Jakarta: Pt Indeks.

[14] Saputro, S. D., \& Setyawan, A. (2020). The Effectiveness Use of Virtual Reality Media in Physics Education of Solar System Towards Cognitive Learning Outcomes. Jurnal Pendidikan Indonesia, 9(3), 389-400.

[15] Semiawan. (1992). Pendekatan Keterampilan Proses: Bagaimana Mengaktifkan Siswa dalam Belajar. Jakarta: Grasindo.

[16] Suastra, I. . (2008). Pembelajaran Sains Terkini, Mendekatkan Siswa dengan Lingkungan Sosial dan Budayanya. Singaraja: Universitas Pendidikan Ganesha.

[17] Sulistiyarini, D., \& Sabirin, F. (2020). 21st Century Literacy Skill of Information Technology and Computer Education Students. Jurnal Pendidikan Indonesia, 9(4), 576-585.

[18] Suryandari, K. C., Sajidan, Rahardjo, S. B., Prasetyo, Z. K., \& Fatimah, S. (2018). Project-Based Science Learning And Pre-Service Teachers' Science Literacy Skill And Creative Thinking. Cakrawala Pendidikan, 37(3), 345-355.

[19] Sutrisno. (2011). Pengantar Pembelajaran Inovatif Berbasis Teknologi Informasi dan Komunikasi. Jakarta: Gaung Persada Press. 
[20] Tanti, D. ., Kurniawan, Kuswanto, Utami, W., \& Wardhana, I. (2020). Science Process Skills And Critical Thinking In Science: Urban And Rural Disparity. Jurnal Pendidikan IPA Indonesia, 9(4), 489-498.

[21] Ulianta, I. K., Sukardjo, M., \& Priono. (2020). Pengaruh Modul Pembelajaran dan Kecerdsasan Intrapersonal terhadap Hasil Belajar kimia Siswa di SMPN 90 Jakarta. Jurnal Teknologi Pendidikan, 22(1), 25-39.

[22] Verawati, N. N. S. P., \& Prayogi, S. (2016). Reviu Literatur Tentang Keterampilan Proses Sains. Prosiding Seminar Nasional Pusat Kajin Pendidikan Sains Dan Matematika, 334-336. Mataram: IKIP Mataram.

[23] Wijaya, I. K. W. B. (2019). Mengembangkan Keterampilan Generik Sains Pada Siswa Sekolah Dasar Untuk Menyongsong Era Revolusi Industri 4.0. Prosiding Seminar Nasional Dharma Acarya, 81-88.

[24] Wijaya, I. K. W. B., Kirna, I. M., \& Suardana, I. N. (2012). Model Demonstrasi Interaktif Berbantuan Multimedia Dan Hasil Belajar Ipa Aspek Kimia Siswa Smp. Jurnal Pendidikan Dan Pengajaran, 45(1).

[25] Wijaya, I. K. W. B., Suastra, I. W., \& Muderawan, I. W. (2014). Pengaruh Model Pembelajaran Generatif Terhadap Keterampilan Berpikir Kreatif dan Keterampilan Proses Sains Siswa. Jurnal Pendidikan Dan Pembelajaran IPA, 4(1). 